\title{
HERPES ZOSTER OPHTHALMICUS IN CHILDREN
}

\author{
BY \\ S. M. TUCKER* \\ From St. Andrew's Hospital, Bow, London
}

(RECEIVED FOR PUBLICATION JANUARY 30, 1958)

Herpes zoster ophthalmicus, first described fully by Jonathan Hutchinson in 1866 , is very rare in children, being predominantly an adult affection (Doggart, 1933; Björk, 1950; Duke-Elder, 1952). Koch (1939), in reporting a case in a child of $5 \frac{1}{2}$ years of age, states that only one other child, aged 12, developed zoster ophthalmicus at the Mayo Clinic before 1938. In a fairly exhaustive analysis of the literature by Poulsen (1955) only 17 cases had been reported in children, three of whom had the disease within the first year of life. Poulsen adds his own contribution, that of a boy of 15 months. Several standard text books (Mitchell Nelson, 1954; Cecil and Loeb, 1951; Price, 1956) make little or no mention of herpes zoster ophthalmicus in infants and children.

Edgerton (1945), in a detailed analysis of herpes zoster ophthalmicus, found about 2,250 cases in the world literature. The average age of these cases was 43 years. He could only find 44 cases under 13 years of age, but did not attempt to differentiate between the epidemic or symptomatic forms. He does, however, state that in the vast majority of cases of ophthalmic zoster, the disease was secondary or symptomatic.

In view of the great deal of evidence which has accumulated recently linking the virus of herpes with that of chickenpox (Bokay, 1909; Brain, 1933; Amies 1934; Weller, 1953; Simpson, 1954; Blank and Rake, $1955)$ it is surprising to find so few authenticated cases of herpes zoster in children, while chickenpox is such a common and highly infectious exanthema. Chickenpox has its maximum incidence in childhood, whereas herpes is more commonly observed from the ages of 20 to 65 years. Edgerton (1945), on the other hand, quotes Evans and Fox (1905) as saying that herpes zoster ophthalmicus was common in the young. They state that one half of their patients were under 14 years of age. Cases of ophthalmic zoster in children have been reported by other authors as well, but few detailed descriptions can be found in

\footnotetext{
* Present address, Middlesex Hospital, London.
}

the British literature. Roll (1920), presenting the case of a child of 3 years, commented on the unusually early age for such a condition.

The following typical case appears to be one of the few documented cases in the British literature of epidemic herpes zoster ophthalmicus affecting the first division of the trigeminal nerve in a child.

\section{Case History}

D.T., a boy aged 6 years, admitted on July 17, 1956, was the fourth child of healthy parents. He had a normal infancy except for frequent bouts of tonsillitis from the age of 2 years which usually improved without treatment. Tonsillectomy was finally resorted to during June, 1955. He also had a bout of diarrhoea earlier in 1955 but this was very mild. He had mumps, measles and whooping cough during infancy and chickenpox in 1952. Three of the other four children had all had chickenpox many years previously and none of them had had herpes zoster at any time. There was no recent history of having been in contact with herpes or chickenpox.

The boy's present illness began four days before admission to hospital, when his main complaints were of abdominal pain and headache. He was kept in bed and observed.

Three days before admission, he began to complain of pain over his left eye associated with mild photophobia. For the following three days he was pyrexial with a temperature range of $99^{\circ}-100^{\circ} \mathrm{F}$., vomited on a few occasions and still complained of abdominal pain and headaches. The pain over his left eye had now become more acute and the child was subsequently admitted for investigation.

On examination his general condition was good but the temperature was raised to $99^{\circ} \mathrm{F}$. He was reluctant to eat and vomited up what was offered to him. His frontal headache was most painful at this stage but again there were no abnormal findings in any of the other systems. Careful daily examination did not reveal any rash or other abnormal physical findings but on the child's fourth day in hospital a mild conjunctivitis of the left eye was noted with some erythema around the eye. No oedema was present. There was no evidence of any vesicle formation.

On July 21, 1956, a classical cutaneous zoster affecting the ophthalmic branch of the left trigeminal nerve was observed which included the nasociliary branch on that 
side (Fig. 1). The vesicles extended only to the midline and involved the left side of the forehead, both upper and lower eyelids, the left eyebrow, and the root of the nose on the left together with the bridge and the tip. Many of the vesicles had broken down. The left eye was now inflamed and swollen and the upper lid overrode the lower as the eye became closed. Conjunctivitis and iritis were also present. The pupil was inactive but the fundi and discs were normal. The vessels appeared engorged. Diffuse corneal oedema was also present with some impairment of sensation. The tension of the eye appeared normal. Two other vesicles were seen elsewhere on the trunk.

On July 22 the herpetic dermatitis had become infected and left keratitis was noted. Atropine $1 \%$ eye drops were instilled into the affected eye and aureomycin $1 \%$ ointment applied to the infected vesicles. The temperature had now risen to $103^{\circ} \mathrm{F}$. and the child was extremely ill. Left pre-auricular adenopathy was present. The temperature remained high until July 25 , when the ophthalmologist reported that iridocyclitis with punctate keratitis was present. It was decided to continue with atropine, and cortisone drops were added four-hourly.

Within a few days the temperature subsided to normal and the child appeared much happier. He began taking food adequately for the first time since the onset of his illness. The cutaneous herpes had improved considerably but it was noted that the hair on the left side of the head, at the upper limit of the ophthalmic division, had thinned

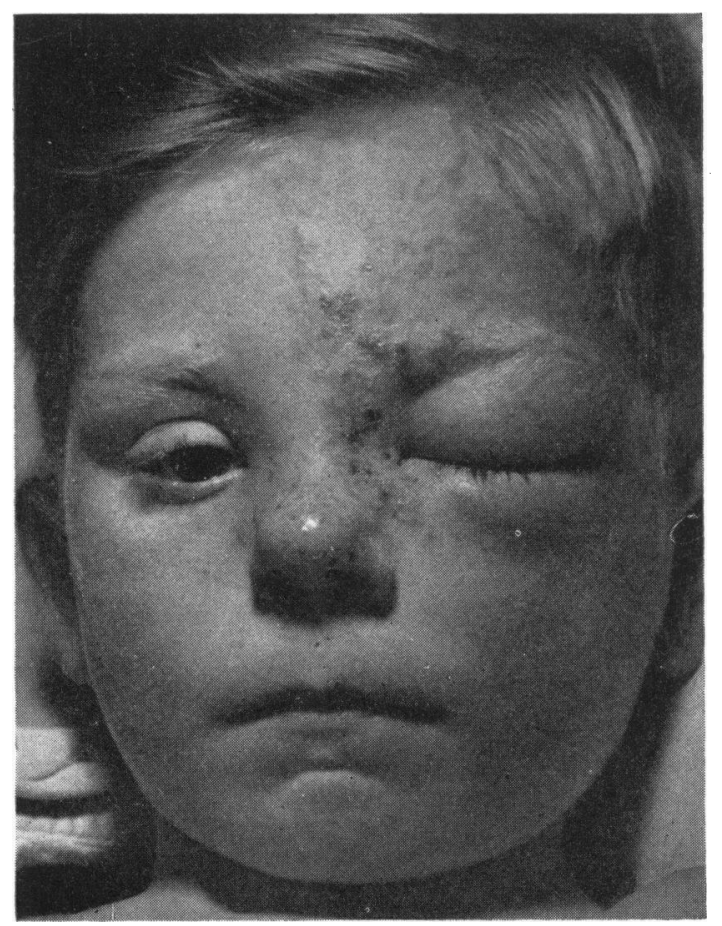

FIG. 1. considerably. The right eye remained normal throughout.

Progress continued and on August 1 the left eye was still mildly inflamed but the chemosis was distinctly less; there was marked ciliary injection and the cornea was very hazy. Typical deep spots were seen in the corneal stroma. Considerable punctate keratitis was present. The pupil was small and was not fully dilated on atropine.

On August 10 keratitis was still present. The eye had become whiter and the pupil was still not fully dilated. The corneal ulcers no longer stained up on fluoroscopy, but characteristic deep white spots were seen in the corneal stroma. Photophobia remained intense.

On August 14 the eye was a little improved, the pupil was wider and there were extensive central nebulae. No corneal sensation was detected. The chemosis and swelling had by this time completely resolved but the herpetiform scars were still evident. The hair was sparse on top but the rash had cleared up.

On September 26, about five weeks later, the cornea showed a ground glass appearance with a few deep residual corneal spots. One month later this had cleared and the corneal haze was noted to be gradually disappearing. No posterior synechiae were present.

In November, 1956, residual corneal dot opacities were still present. Vision in the left eye was only $6 / 60$. The left pupil had now become eccentric. The hair on the forehead had begun to grow again but was still not normal.

Vision improved as the months went by and was found to be 6/36 in the left eye by February, 1957.

He was last seen in June, 1957, one year after the initial infection, when he was found to have supraorbital scarring, normal hair growth of the left forehead, and an eccentric left pupil. Vision had now improved to $6 / 9$. He had been very well in himself for the past few months and had resumed schooling. Sensation in the left eye had returned to normal.

\section{Discussion}

Herpes zoster ophthalmicus usually follows a mild course in children, and it is the rule that all traces of the infection clear up with little residual damage. Ocular complications are usually mild and the children do not appear unduly perturbed by the disease. Post-herpetic neuralgia, so common in affected adults, rarely troubles the child (Björk, 1950).

This case differs from the general observations in some essential points. The child was extremely ill and toxic once the herpes became evident, most unlike many of the cases reported (Poulsen, 1955). Loss of hair in the ophthalmic division was very noticeable and this finding does not appear to have been commented upon much previously. Normal vision had not completely returned one year after the original illness, although improvement has been maintained.

Aetiologically, two types of herpes zoster ophthalmicus are described (Duke-Elder, 1952): (1) The epidemic form which is caused by a specific virus and produces a lesion in every way comparable with 
herpes zoster elsewhere. This form is usually of sudden onset with severe constitutional disturbances such as fever, prostration and vomiting and these general signs often precede the neuralgic pain of the herpes. (2) The symptomatic form due to the involvement of the ganglion secondarily in infective, neoplastic or traumatic disturbances, e.g. syphilis, tuberculous meningitis or a pontine tumour. It may also be caused by drugs, e.g. arsenic or carbon monoxide poisoning. This form cannot be definitely diagnosed as such unless the patient shows other evidence of the causal agent, which may not appear until months or years later. Many of the cases reported in children may well be this symptomatic form with the evidence or cause of the trouble as yet not manifest.

The case described falls into the first group. DukeElder states that herpes zoster ophthalmicus of the epidemic type almost always affects adults and the aged; it runs a fairly similar course in all cases from onset to subsidence.

Doggart (1933) lists three principal features in the diagnosis of epidemic herpes zoster: (1) Pain along the course of distribution of the first division of the fifth cranial nerve; (2) A skin rash appearing about three days later on a portion of the corresponding area of the face or head; (3) Limitation of the rash to one side.

Ocular complications usually occur in about $50 \%$ of adults affected, the main ones being keratitis, iritis, scleritis, ocular muscle palsies and optic neuritis. If the naso-ciliary branch of the ophthalmic division of the trigeminal nerve is involved by a lesion of the tip of the nose, the eye will very often be involved as well (Hutchinson, 1866). This case illustrates the rule quite convincingly.

Relation of Herpes Zoster to Varicella. The virus causing herpes zoster is now believed to be identical with the virus of varicella and there is a large amount of clinical and experimental evidence for the association (Bokay, 1909; McEwen, 1920; Jacobi, 1921; Simpson, 1954; Blank and Rake, 1955).

Minor antigenic differences may be present but the two viruses appear to be very closely related. They may differ perhaps in the mode of attack by the virus: in herpes zoster spread is by the lymphatics, whereas in chickenpox it is usually via the blood stream (Low, 1919). There remains the possibility of the occurrence of two forms of epidemic herpes zoster, one allied to chickenpox and one allied to herpes. Most evidence, however, supports the monistic theory that zoster and chickenpox are different manifestations of infection by the same virus, zoster being usually a reawakening of the latent infection of chickenpox (Blank and Rake, 1955).

Simpson (1954) after studying an epidemic on the Shetland Island of Yell of ordinary varicella and also of varicella caught from a shingles contact on the same island, could find no distinction in the clinical manifestations, in the mean reproductive cycles, in the infectiousness of the disease or in the solidity of the protection conferred by a previous attack against varicella of the same or of the alternative origin, i.e. complete cross immunity, and concluded that the varicella caught from shingles is due to the same virus as ordinary chickenpox. He also showed that people infected with chickenpox derived from a case of zoster were subsequently immune for a few years to ordinary chickenpox infection; and similarly, people who had previously had chickenpox were not infected when exposed to the virus derived from a case of zoster.

Experimental evidence of Kundratitz (1925) and Bruusgaard (1932) as early as 1925 is in line with the views expressed by Simpson (1954) and they offer laboratory evidence of close similarities between the two aetiological agents.

\section{Summary}

Herpes zoster ophthalmicus is a rare form of herpes infection in children, being primarily an adult affection. A case of a boy of 6 years is presented who showed the classical unilateral eruption together with some other unusual features. The association of the herpes zoster virus with varicella is discussed.

I am indebted to Dr. B. D. R. Wilson under whose care the child was admitted for helpful advice and criticism and to Mr. L. M. Green for ophthalmological comments.

\section{REFERENCES}

Amies, C. R. (1934). Brit. J. exp. Path., 15, 314.

Amies, C. R. (1950). Acta derm.-venereol.' (Stockh.), $30,34$.

Blank, H. and Rake, G. (1955). Viral and Rickettsial Diseases of Skin, Eyes and Mucous Membranes of Man. Boston.

Bokay, J. von. (1909). Wien. klin. Wschr., 22, 1323.

Brain, R. T. (1933). Brit. J. exp. Path., 14, 67.

Bruusgaard, E. (1932). Brit. J. Derm., 44, 1.

Cecil, R. L. and Loeb, R. F. (1951). Textbook of Medicine. London and Philadelphia.

Doggart, J. H. (1933). Brit. J. Ophthal., 17, 513. Duke-Elder, S. (1952). In Textbook of Ophthalmology. Vols. II
and V. London.

Edgerton, A. E. (1945). Arch. Ophthal. (Chicago), 34, 40, 114.

Evans and Fox. (1905). Brit. J. Derm., 17, 199

Hutchinson, J. (1866). Ophth. Hosp. Rep. 3, 72; 5, 191.

Jacobi, O. (1921). Z. Kinderheilk., 29, 368.

Koch, F. L. P. (1939). Arch. Ophthal. (Chicago), 21, 118.

Kundratitz, K. (1925). Wien. klin. Wschr., 38, 502.

Low, R. C. (1919). Brit. med. J., 1, 91.

McEwen, E. L. (1920). Arch. Derm. Syph., 2, 205

Nelson, W. E. (1954). In Textbook of Puediatrics, 6th ed. London and Philadelphia.

Poulsen, P. A. (1955). Acta med. scand., 151, 131.

Price, F. W. (1956). In Textbook of Medicine, 9th ed., London.

Roll, G. W. (1920). Proc. roy. Soc. Med., 13,81.

Simpson, R. E. H. (1954). Lancet, 2, 1299.

Weller, T. H. (1953). Proc. Soc. exp. Biol. (N.Y.), 83, 340. 